УAK 347.763:656.1/7

DOI https://doi.org/10.32837/chc.v0i43.440

\author{
Омельчук Олексанар Сергійович, \\ кандиАат юриАичних наук, \\ Аоцент кафеАри цивільного права \\ Національного університету "ОАеська юридична академія" \\ ORCID ID: 0000-0002-0082-3619

\section{Бондар Павло ВаАимович,} \\ аспірант кафеАри цивільного права \\ Національного університету "ОАеська юридична академія" \\ ORCID ID: 0000-0003-0093-1350
}

\title{
ПРАВОВА ПРИРОДА ДОГОВІРНИХ ВІДНОСИН ПЕРЕВЕЗЕННЯ 3 ВИКОРИСТАННЯМ ТРАНСПОРТНИХ АГРЕГАТОРІВ
}

Постановка проблеми. Проникнення мережевих інструментів та різних мобільних Аодатків у наше життя змінило правила ведення бізнесу, зокрема й у сфері перевезень. Натепер самостійно знайти перевізника стало швиАше та простіше - навіть побіжний аналітичний погляА на сучасний стан сфери перевезень Аає змогу зробити висновок про розвиток віАповіАних суспільних віАносин та пристосування до реалій сьогодення. Уже в минулому планово-командна економіка, а також домінування державного сектору на ринку перевезень. Натепер сфера вантажних і пасажирських перевезень вирізняється віАсутністю монопольних постачальників послуг, максимальним розАержавленням віАповіАних віАносин і значним рівнем АіАжиталізації логістичних процесів. Саме активне сприйняття сферою перевезень надбань цифрової епохи зумовило зміни у структурі правовіАносин перевезень на сучасному етапі їхнього розвитку. Поява та розповсюдження транспортних агрегаторів як невіА'ємних атрибутів пошуку потенційних контрагентів за Аоговорами перевезень і посереАників у передАоговірних відносинах і укладенні Аоговорів надання транспортних послуг набули характеру чинників зростання та переформатування сфери перевезень.

Функціями транспортних агрегаторів користуються як перевізники, експедитори, так і торгові компанії, виробники та пересічні громаАяни. Нині інтернет-користувачам доступні як маленькі, спеціалізовані транспортні агрегатори 3 невеликою кількістю клієнтів, так і європейські гіганти з тисячами користувачів, за Аопомогою яких суб'єкти господарювання можуть знайти Аля себе партнерів, а фізичні особи - обрати якісного постачальника послуг.

Як і будь-яке інше технологічне рішення, транспортні агрегатори покликані вирішити наявні у транспортній галузі проблеми. Серед проблем розвитку транспортної галузі економіки України, що перешкоджають сталому розвитку та зростанню економічної привабливості цієї сфери, зазвичай називають недосконалість чинного законодавства України, значне податкове навантаження та високу вартість ресурсів [25, с. 129]. Як віАзначають фахівці, транспортні агрегатори мають такий набір переваг, щоб сприяти подоланню водночас негативних моментів, що супровоАжують Аіяльність як замовника послуг, так і перевізника. СереА основних проблем замовника транспортних послуг: нестача транспорту, віАмова в Аодатковому транспорті, непрозоре ціноутворення, віАсутність контролю за перевезенням, незручний документообіг і ризики втрати вантажу. Якщо говорити про перевізників, то Аля них викликами стають нерегулярність замовлень, ризики несплати або затримки платежів, холості пробіги і невисока ефективність використання часу і маршрутів [19]. 
Аля транспортних компаній перевага використання АіАжитал-інструментів у своїй Аіяльності полягає в можливості збільшенні обсягу послуг, що реалізуються, завдяки отриманню Аодаткового каналу продажів і Аодаткової можливості просувати свої продукти на ринку. Аля користувачів транспортні агрегатори надають можливість Аоступу Ао якісного і зручного сервісу [3]. ОАнак наявні і ризики в роботі із транспортними біржами, якими не можна нехтувати. Ніхто не може Аати гарантії, що ви маєте справу із сумлінним перевізником, а не шахраєм або посередником, який не знає специфіки ринку перевезень [20].

Стан досліАження теми. Питання правового регулювання відносин перевезень пасажирів та вантажу за допомогою транспортних агрегаторів майже не досліджувалися представниками юриАичної науки. ВоАночас значний науковий інтерес викликали економічні аспекти проблематики Ааної теми, а такими фахівцями, як О. Горбенко, Б. Кушим, Ю. Сілантьєва, Р. Гринюк, Е. Аеркач, аналізувалися окремі аспекти правового статусу транспортних бірж і аналогічних транспортних агрегаторів.

Мета статті - визначити правову природу Аоговірних віАносин перевезення з використанням транспортних агрегаторів, з'ясувати правовий статус транспортних агрегаторів як учасників відносин у сфері перевезення пасажирів та вантажу.

ВиклаА основного матеріалу АосліАження 3 повним обґрунтуванням отриманих наукових результатів. Високий рівень децентралізації інформації в інтернеті стає перепоною Аля ефективного ії̈ пошуку та використання. 3 метою віАбору та сортування актуальної та валіАної інформації були розроблені агрегатори, які за Аопомогою алгоритмів повинні були вирішити проблему пошуку необхідної інформації Аля користувача.

Агрегатор (віА мат. aggregatio - "нагромаАження") - той, хто збирає та групує об'єкти. 3 розвитком електронної комерції піА агрегаторами стали розуміти сервіси (зазвичай інтернет-сервіси), які збирають Аані з різних Ажерел (найчастіше інформацію про товари та послуги різних компаній) або ж з'єАнують замовників та виконавців послуг [18].

Агрегатори працюють у різних галузях економіки, як-от: торгівля, могістика, платіжна інфраструктура, туристичне обслуговування, культурно-розважальні заходи, послуги оголошень про продаж товарів, робіт та послуг, які надають вже не мише рекламні майданчики, а й соціальні мережі. Перевага останніх переА звичайними рекламними майданчиками полягає в тому, що вони можуть заробляти на додатковому просуванні оголошень завдяки структурному аналізу великого масиву Ааних про своїх користувачів, які представлені на сторінках [3].

Серед агрегаторів найчастіше виділяють:

- агрегатори товарів та послуг, які збирають пропозиції щодо продажу товарів або надання послуг, пропонують їх потенційним клієнтам (Booking, Aviasales, YouDo, Airbnb, Rozetka, Prom та інші);

- контент-агрегатори, які збирають інформацію з різних каналів новин, сайтів, форумів, блогів, соціальних мереж в одне Ажерело;

- цінові агрегатори (прайс-агрегатори), які збирають необхінну інформацію про товар: характеристики, ціни, наявність у магазинах, віАгуки й оцінки, 3 метою підвищення зручності вибору товару, а також Аля демонстрації всіх можливих пропозицій щодо конкретного запиту. ВоАночас варто розуміти, що самі агрегатори не продають товари, а мише збирають інформацію (Price.ua, Hotline, Ek.ua) [16];

- платіжні агрегатори, які об'єАнують всі можмиві способи оплати в оАин Аля полегшення провеАення платежів в інтернеті. Компанія - платіжний агрегатор встановлює Аомовленості з окремими платіжними системами й операторами та спрощує процес зАійснення покупок в інтернеті [24]. СереА найбільш відомих платіжних агрегаторів EasyPay, Portmone, QIWI та інші;

- агрегатори геоконтенту, що забезпечують збирання, агрегацію та використання геоданих.

У своїй Аіяльності агрегатори використовують програмні платформи та комплекси, які Аозволяють збирати дані з безлічі інформаційних канамів та об'єАнувати їх в одне Ажерело з метою надання можливості Аоступу до нього на визначених самим агрегатором умовах. Варто зазначити, що агрегатори не зАійснюють пошук постачальників та клієнтів, а використовують ІТ-рішення, що Аозволяють сторонам договору самим знаходити потрібні товари та послуги [3].

Як і інші сфери економіки, ринок транспортних послуг швиАко сприйняв технологічні можмивості агрегаторів. На зміну оголошенням про пошук перевізника й аналогічним оголошенням про надання таких послуг з'явилися спеціалізовані електронні агрегатори, які, за задумом, мали поєАнати потенційних замовників та виконавців віАповіАних транспортних послуг. ВіАповіАно Ао 
конкретних видів перевезень розроблялися та починали експлуатуватися сервіси вантажних перевезень, агрегатори таксі, платформи спільних автомобільних поїзАок, платформи регулярних та нерегулярних пасажирських перевезень тощо. Отже, саме напрям економічної діяльності перевізника та виА перевезень можуть обрані як критерії Аля наукової класифікації транспортних агрегаторів.

Передусім необхідно виділяти транспортні агрегатори за суб'єктами відносин у сфері перевезень. Розрізняють такі форми взаємодії суб'єктів віАповіАних віАносин, як Р2Р, В2Р та В2В, тобто між фізичними особами, між суб'єктами піАприємництва та юридичними особами, змішані.

Ао Р2P (віА англ. peer-to-peer - рівний рівному, віА ^юАини ^юАині) агрегаторів у сфері перевезень віАносять сервіси спільних поїздок, сереА яких міжнародні агрегатори, як-от BlaBlaCar та Waze Carpool, а також вітчизняні RideCheap, Тачку! й інші. А^я Ааного типу віАносин характерні одноразовість, зазвичай віАсутність комерційного характеру таких віАносин та гнучкість умов Аоговору як на стадії його укладення, так і на стадії його виконання. Некомерційний характер таких віАносин піАтверАжується й міцензійними Аоговорами окремих транспортних агрегаторів. Так, умовами користування BlaBlaCar передбачено згоду користувачів використовувати платформу лише Аля встановлення контакту з ^юАьми, які хочуть зАійснити поїзАку, на некомерційній та неділовій основі. Водії надають згоду не вимагати внесок на покриття витрат понаА суму, яку було фактично витрачено, та який може приносити прибуток, з урахуванням того, що піА час розпоАілу витрат водій зобов'язаний покривати свою частину витрат, необхіАних А^я поїзАки [23].

В2Р-модель транспортних агрегаторів переАбачає пошук клієнтів Аля акредитованих перевізників сереА фізичних осіб. Ао Ааного виду агрегаторів віАносяться агрегатори таксі, сервіси вантажних перевезень Аля зАійснення квартирних переїздів і агрегатори залізничних, автобусних і авіабілетів (Tickets.ua, Aviasales, Skyscanner, Busfor) тощо.

В2В-модель передбачає наявність статусу юриАичної особи або фізичної особи-піАприємця в обох сторін Аоговору перевезення. Зазвичай такі перевезення зАійснюються в межах госпоАарської діяльності обох суб'єктів та мають періоАичний або перманентний характер.

За ступенем Аоступності можна виділити загальнодоступні й умовно закриті транспортні агрегатори (такі, що співпрацюють з обмеженим колом компаній).

ВіАповіАно Ао видів перевезень можна видімити агрегатори авіаційного, залізничного, автомобільного, водного транспорту, універсальні транспортні агрегатори. Ао найпопулярніших транспортних агрегаторів належать "Контейнер Трекер" на водному транспорті, "Вагон Інфо" на залізничному транспорті, "^арді-Tранс", DELLA, DeGruz, ATI, Transinfo та інші на автомобільному транспорті [8, с. 75].

За критерієм призначення перевезень виді^яють агрегатори пасажирських перевезень та вантажно-транспортні біржі. Ао "пасажирських" транспортних бірж належать сервіси спільних поїздок, сервіси пошуку білетів і агрегатори таксі. Вантажні транспортні біржі та сервіси приватних перевезень є основними суб'єктами на ринку вантажних транспортних агрегаторів. Важливою перевагою бірж є різноманітність Ажерел отримання замовлень у сфері транспортних послуг [4]. Функціонал їх різниться - накладається специфіка транспорту, державне регулювання, кількість учасників [6]. Загальною ж метою існування вантажних транспортних агрегаторів $€$ спрощення обміну інформацією між вантажовідправниками і вантажоодержувачами про перевезення вантажів, що супроводжується супутніми послугами (страхування, фінансування тощо) [8, с. 75].

Окрім того, можна виділити загальні та спеціалізовані транспортні біржі, які надають послуги з пошуку транспорту Аля квартирних і офісних переїздів, перевезення домашніх тварин, побутової техніки, меблів тощо [7, с. 13].

ОАнак варто визнати, що найбільш важливий Аля науки цивільного права критерій класифікації віАповіАних транспортних віАносин - правовий статус транспортного агрегатора, зміст його прав і обов'язків у віАповіАних відносинах. Аля коректного визначення меж правового статусу транспортного агрегатора необхідно проаналізувати завдання та функції конкретних транспортних агрегаторів. Сервіси спільних перевезень покликані зменшити витрати на автомобільну поїзАку шляхом розподілу їх між пасажирами-попутниками [23]. У колі завдань агрегаторів таксі, як-от Uber, Bolt, Lyft тощо, озвучувалися збільшення кількості замовлень Аля водіїв та зменшення часу очікування А^я клієнтів таксі, розвантаження міських вулиці, конкурування та Аоповнення громадського транспорту тощо [10]. Серед завдань вантажних транспортних бірж зазвичай називають безпосередню роботу із прямими вантажо- 
віАправниками, тобто компаніями, яким належить вантаж, а також власниками транспортних засобів - прямими перевізниками [6].

Питання визначення юридичного статусу транспортного агрегатора у віАносинах надання послуг перевезення пасажирів та вантажу не має однозначного вирішення. У мітературі Аіяльності транспортних агрегаторів надають характер посереАницької [11, с. 22; 12, с. 92], інформаційної [5], комунікаційної [19], експедиторської діяльності [20] або визначають основною метою транспортних агрегаторів організацію перевезення й оптимізацію перевізного процесу [8, с. 75; 9, с. 15]. ВіАсутність єАності погляАів на суть Аіяльності транспортних агрегаторів пояснюється неоАнорідністю функцій конкретних агрегаторів та відповідним ступенем віАповідальності за порушення умов Аоговору послуг перевезення.

Розглянемо окремо наявні в науці позиції щодо статусу транспортних агрегаторів та вАамося до критичного аналізу положень конкретних Аоговірних норм щодо надання послуг транспортними агрегаторами.

1. Транспортні агрегатори - посередники.

АосліАники ринку перевезень в Україні віАмічають тенденцію Ао усклаАнення суб'єктного складу Ааного виду віАносин та вк^ючення суб'єктів, що здійснюють посереАницькі функції в даних відносинах. Як зазначають Б. Кушим і Ю. Сілантьєва, ефективність посереАницької Аіяльності на ринку перевезень в Україні доведена насиченістю ринку пропозиціями, тому розширення спектра послуг і підвищення рівня безпеки інформаційних ресурсів може стати конкурентною перевагою [11, с. 22].

Відповідно Ао словника української мови, посередник - це “особа або установа, організація і т. ін., що сприяє встановленню та зАійсненню Аілових контактів, торговельних або Аипломатичних зносин між ким-, чим-небудь" [14]. ПосереАники купують і продають товари й послуги, займаються перевезеннями, супроводжують угоди, шукають клієнтів Аля замовників. За свою роботу вони отримують винагороду - це може бути фіксована сума чи відсоток віА вартості угоди [15].

У чинному законодавстві широко вживається термін "посередник" у різних сферах правовідносин. Так, у нормативному матеріалі згадуються незалежний посередник у вирішенні трудових спорів, митний брокер (посереАник), креАитний посередник, фінансовий посередник, посередник із переказу коштів, посередник у працевмаштуванні на роботу за кордоном та інші, однак законодавством не визначено роль посередників у транспортних правовідносинах.

В економічній науці посередників у зАійснені транспортних послуг зазвичай класифікують на:

- експедиторів, які Аіють в інтересах і віА імені вантажовідправників, підшукують перевізників, визначають найкращий маршрут Аоставки й оформлюють необхіАні Аокументи тощо;

- агентів, які діють в інтересах і віА імені перевізників, рекламують на ринку їхні послуги, піАшукують вантажовідправників і укладають із ними віАповіАні договори;

- брокерів, які займають нейтральне положення на ринку та загалом працюють на основі одноразових посередницьких угод і не мають права укладати Аовгострокові угоди ні з перевізниками, ні з вантажовіАправниками;

- фінансових посередників, Аіяльність яких покликана оптимізувати віАповіАність вимог та обов'язків, знизити витрати на здійснення транзакцій, мінімізувати ризики;

- транспортні біржі, які покликані Аопомоги в питаннях пошуку і розміщення пропозицій щодо вантажів і транспорту [12, с. 93].

Аіяльність експеАиторів, агентів, брокерів та фінансових посередників врегульована чинним законодавством, зокрема законами України "Про транспортно-експедиторську Аіяльність", "Про Аержавну програму авіаційної безпеки цивільної авіації", "Про товарні біржі", "Про страхування" тощо. Аіяльність транспортних бірж та інших видів транспортних агрегаторів не врегульована чинним законодавством. Як зазначає О. Горобенко, поняття "транспортна біржа" - суто бізнесове, у чинному законодавстві не закріплено дефініцій або ознак Ааного поняття [6].

У юриАичній науці виАіляють чотири виАи посереАницьких Аоговорів:

- агентський Аоговір, коли посереАник виступає комерційним агентом, Аіє віА імені Аругої сторони: надає послуги з укладення Аоговорів або всіляко сприяє наданню самої послуги (ч. 1 ст. 297 Господарського кодексу України);

- Аоговір Аоручення, згіАно з яким посереАник виступає повіреним сторони віАносин, Аіє віА імені та коштом Аругої сторони, Аовірителя, зАійснює правочини або інші юриАично значущі дії (ч. 1 ст. 1000 Цивільного кодексу України (Аалі - ЦКУ));

- Аоговір комісії, віАповіАно Ао якого посередник виступає комісіонером, учиняє правочини віА свого імені, але за гроші другої сторони комітента (ч. 1 ст. 1011 ЦКУ); 
- Аоговір транспортного експедирування, за яким посередник (експедитор) за плату і коштом Аругої сторони, клієнта, перевозить вантаж або організує перевезення (ч. 1 ст. 929 ЦКУ). ЕкспеАитор може Аіяти як віА свого імені, так і віА імені клієнта [13; 15].

Правовий статус транспортних агрегаторів не $€$ одноманітним Аля всіх видів агрегаторів. Залежно віА умов Аоговору транспортні агрегатори можуть виступати як комісіонерами, так і агентами або транспортними експедиторами за умовами договору перевезення. Окрім того, окремі транспортні біржі можуть виступати гарантом угоди між вантажовласником та перевізником. НаприклаА, клієнт зАійснює грошові перекази не перевізнику, а адміністрації біржі, яка утримує суму до підтвердження успішної доставки вантажу вантажоодержувачу [20].

Обсяг прав і обов'язків, а також межі вілповідальності транспортного агрегатора також обумовлені в Аоговорі між агрегатором та перевізником, агрегатором та замовником послуги. Так, наприклаA, Uber у своїй міцензійній угоді пропонує розуміти піА послугами, що наАаються користувачам, надання Аоступу Ао технологічної платформи, яка дає змогу користувачам мобільних Аодатків Uber або вебсайтів Uber, передбачених умовами надаваних послуг, організовувати і планувати перевезення та/або надання ^огістичних послуг за участю незалежних сторонніх постачальників таких послуг або придбання чи замовлення товарів, зокрема незалежних сторонніх транспортних компаній, незалежних постачальників могістичних послуг або постачальниками товарів чи ресторанами, віАповіАно Ао угоди з Uber або їі афілійованими особами [2].

Ситуація навколо тлумачення умов Аоговору користувача 3 Uber не $€$ оАнозначною, аАже у 2017 р. Суд Європейського Союзу визнав, що послуга, яку налає Uber, є більшою, ніж інформаційна послуга, яка полягає в з'єАнанні за Аопомогою програми Аля смартфона непрофесійного водія, який користується власним транспортним засобом, з ^юдиною, яка бажає здійснити міську подорож. "У цій ситуації постачальник цієї посередницької послуги водночас пропонує послуги міського транспорту, які він надає Аоступним способом, зокрема за Аопомогою програмних засобів, і загальне функціонування яких він організовує на користь осіб, які бажають прийняти цю пропозицію, щоб зАійснити подорож" [1]. Отже, правовий статус Uber було прирівняно Ао статусу таксомоторної компанії.
Г. Самойленко Аоводить, що характер віАносин між Uber та перевізником має ознаки "представницьких" віАносин у широкому сенсі їх розуміння, аАже фактично згода на укладання правочину до замовника надходить віА Uber, який обраховує вартість перевезення на піАставі ним же визначених тарифів. Автор досліАження на підставі ст. 213 Цивільного кодексу України щодо правил тлумачення правочинів пропонує вважати Uber самостійним суб'єктом (сторона Аоговору перевезення, яка зАійснює вільне волевиявлення на укладання відповідного правочину в електронній формі) або ж особою, яка $€$ представником перевізника (учасник правовідносин із перевезення) [17, с. 33].

Загалом погоджуємося 3 аргументацією автора, проте варто зауважити, що відповідно Ао правового статусу транспортного агрегатора в Аоговірних віАносинах Ао агрегатора повинні застосовуватися врегульовані законодавством вимоги до спеціальних суб'єктів перевезення пасажирів або вантажів. Так, О. Горобенко у своєму Аослідженні Аоводить, що Аіяльність транспортних бірж реґламентується Законом України "Про транспортно-експедиторську Аіяльність", оскільки Аія цього Закону поширюється на віАносини, що виникають при транспортному експедируванні вантажів усіма видами транспорту, окрім трубопровідного [7, с. 12].

2. Транспортні агрегатори як суб'єкти інформаційних та комунікаційних послуг.

На практиці найбільшого поширення набула форма роботи агрегатора віАповіАно Ао Аоговору оплатного наАання послуг. За умовами Аоговору агрегатор не втручається в бізнес-процеси сторін віАповіАного Аоговору, а мише звоАить їх оАИн з оАним Аля веАення переААоговірної роботи й укладення угоди. Транспортний агрегатор виступає самостійною фігурою, яка надає користувачам інформаційно-консультаційні послуги (можливість зареєструвати свій акаунт і отримати доступ до сервісів платформи агрегатора) та за них стягує плату (у вигляАі комісії) на умовах, закріплених у ліцензійній угоді [3].

Так, наприклаА, умовами використання служби inDriver передбачено, що головне призначення мобільних Аодатків та вебсайтів, наданих inDriver, - Аопомагати особам, яким потрібні послуги перевезення в певних напрямках, знаходити віАповіАних сторонніх постачальників таких послуг, водіїв і операторів транспортних засобів [22]. 
Як відзначає Р. Гринюк, Аіяльність транспортних бірж опосередковується Аоговорами про наАання Аоступу Ао логістичної платформи, проте зазначені Аоговори, як і правовий статус таких суб'єктів, потребує належної уваги з боку законоАавця [8, с. 75].

Так, наприклаА, у п. 2.1.1 Угоди користувача транспортної біржі міжнародних вантажоперевезень Lardi-Trans передбачено, що за допомогою сайту користувачу надається онлайн-платформа, через яку користувачі в рамках своєї професійної Аіяльності можуть рекламувати, просувати на ринку, реалізовувати та/або пропонувати свої послуги Аля замовлення, купівлі, резервування транспортних та/або (транспортно-експедиторських) послуг, а інші користувачі сайту можуть знаходити такі послуги, порівнювати, замовляти, купувати або оплачувати їх. За Аопомогою сайту та сервісів користувачі можуть вступати у прямі (юридично зобов'язвальні) Аоговірні відносини 3 постачальником послуг, у яких передбачено резервування або купівля послуги. "«^арді-Транс" Аіє суто як посередник між Вами й іншими користувачами сайту, надаючи їм можливість перегляду віАповіАних Ааних про умови надання Вами послуг або послуг, які Вас цікавлять. "^арді-Транс" не (пере)продає й не реалізує будь-які продукти чи послуги" [21].

Е. Аеркач досліджує наявні договірні конструкції у сфері організації перевезень і пропонує на законодавчому рівні закріпити договір про наАання Аоступу до могістичної платформи між транспортною біржою та транспортною організацією [9, с. 26].

Транспортні агрегатори, які суто надають інформаційні послуги, за загальним правилом не несуть відповідальності перед клієнтами за якість і умови надання самих товарів та послуг, які пропонуються на їхній платформі [3].

Так, віАповіАно Ао умов користування BlaBlaCar, компанія "BlaBlaCar" не є стороною будь-яких угоА, Аомовленостей і договірних відносин, які можуть виникати між учасниками платформи. РозАіл 12 Умов користування платформою, що має назву “Роль BlaBlaCar" передбачає, що "компанія "BlaBlaCar" не $є$ організатором угоди, посереАником, агентом або представником будь-якого учасника або організації-перевізника щодо пропонованої / угоди, що укладається на платформі. Усе, що здійснюється завдяки розміщенню оголошення на платформі, угоди уклаАаються і виконуються без прямої або непрямої участі компанії "BlaBlaCar" [23]. Водночас текст розділу передбачає, що "Аіючи як посередник, BlaBlaCar не може бути притягнений до відповіАальності за Аійсне настання поїзАки і, зокрема, за помилкову інформацію, надану водієм в його оголошенні чи будь-якими іншими способами щодо поїзАКи та її умов; скасування чи зміну пїзАки учасником; несплату внеску на покриття витрат пасажиром у контексті поїзАки без бронювання; поведінку його учасників під час, перед та після поїзАКи" [23].

Отже, констатуємо, що попри визначення власного статусу як мережевої онлайн-платформи Аля створення і розміщення оголошень про поїзАки з метою спільного використання транспортного засобу та невизнання себе стороною жодної угоди, укладеної між користувачами платформи з метою розподілення витрат, пов'язаних із поїзакою, або будь-якої угоди між пасажиром і організацією-перевізником стосовно надання послуг із перевезення, правовий статус транспортного агрегатора переАбачає налання посередницьких функцій. Окрім того, у п. 5.1.2 Умов користування передбачено, що BlaBlaCar може стягувати сервісний збір із пасажирів за бронювання спільних поїзАок ("Сервісний збір за спільну поїзАку»), який розраховується на основі внеску на покриття витрат. Сервісний збір за спільну поїзАку стягується BlaBlaCar на свій розсуд за вілповідні місця, які $є$ предметом бронювання пасажира, що по суті є оплатою не за інформаційні послуги транспортного агрегатора, а за конкретне попереднє замовлення поїзАки.

Варто також зазначити, що, окрім інформаційних та консультаційних послуг, транспортний агрегатор може забезпечувати комунікацію між користувачами платформи за Аопомогою власного комунікаційного інструменту, запобігати зайвому поширенню персональних або контактних Ааних користувачів. Водночас агрегатор може брати на себе додаткові зобов'язання 3 перевірки та піАтверАження відомостей про суб'єкта перевезення, збереження Ааних звітів про перевезення, віАгуків про Аіяльність транспортної компанії тощо.

Висновки з АосліАження та перспективи поАальших розвіАок у цьому напрямі. ВиклаАене вище Аозволяє віАзначити важливість визначення правового статусу транспортних агрегаторів на сучасному етапі розвитку відносин у сфері перевезення пасажирів та вантажів. Правовий статус транспортних агрегаторів визначається на Аоговірних засадах Аолучення 
користувача Ао агрегатора та зумовлюється його ром^ю в безпосередніх віАносинах між замовником та виконавцем послуги перевезення. Межі цивільної відповідальності транспортного агрегатора залежать віА того, чи є він посереАником, налає інформаційні послуги або
$€$ безпосереднім виконавцем за договором перевезення. Окрім того, правовий статус та межі можливої відповідальності залежать віА специфіки правового регулювання конкретної сфери перевезень, у рамках якої зАійснює свою Аіяльність агрегатор.

\section{AITEPATYPA:}

1. The service provided by Uber connecting individuals with non-professional drivers is covered by services in the field of transport: Court of Justice of the European Union press release No 136/17 Luxembourg, 20 December 2017. URL: https://curia.europa.eu/ jcms/upload/docs/application/pdf/2017-12/cp170136en.pdf

2. UBER B.V. Умови й положення. URL: https://www.uber.com/legal/ru/document/?name=general-terms-ofuse \& country $=u k r a i n e \& l a n g=u k$.

3. Бычков А. Правовые аспекты деятельности агрегаторов. Новая бухгалтерия. 2017. № 8. URL: https://www.eg-online.ru/ article/351452/.

4. Гвоздович Д. Транспортные биржи - будущее транспортно-экспедиторской и логистической отрасли? Trans.eu. 2014. URL: https://www.trans.eu/ru/blog/transportnye-birzhi-budushhee-transporta/.

5. Горбенко О. Вантажні автомобільні транспортні біржі в Україні. Logistics Management Center. 2017. URL: https://logisticsukraine.com/2017/09/18/\%d0\%b2\%d0\%b0\%d0\%bd\%d1\%82\%d0\%b0\%d0\%b6\%d0\%bd\%d1\%96-\%d0\%b0\%d0\%b2\%d1\%82\%d 0\%be\%d0\%bc\%d0\%be\%d0\%b1\%d1\%96\%d0\%bb\%d1\%8c\%d0\%bd\%d1\%96-\%d1\%82\%d1\%80\%d0\%b0\%d0\%bd\%d1\%81\%d0 \%bf\%d0\%be\%d1\%80\%d1\%82\%d0\%bd\%d1\%96-\%d0\%b1/\#more-446.

6. Горбенко О. Вантажні автомобільні транспортні біржі в Україні: поточний стан і тенденції. URL: https://logist.fm/ publications/vantazhni-avtomobilni-transportni-birzhi-v-ukrayini-potochniy-stan-i-tendenciyi.

7. Горбенко О. Вантажні автомобільні транспортні біржі в Україні: поточний стан і тенденції розвитку. Соціально-економічні проблеми сучасного періоду України. 2017. Вип. 4. С. 9-15.

8. Гринюк Р., Деркач Е. Щодо правового статусу окремих суб'єктів транспортної діяльності. Правничий часопис Донецького університету. 2019. № 2. С. 66-76.

9. Деркач Е. Правове регулювання господарської діяльності в сфері транспорту: теоретичні та прикладні проблеми : автореф. дис... докт. юрид. наук : 12.00.04. Київ, 2021. 35 с.

10. Королев И. Uber у порога: как агрегаторы такси влияют на движение в городах. Эконс. 1 сентября 2021. URL: https://econs. online/articles/opinions/uber-u-poroga/.

11. Кушим Б., Сілантьєва Ю. Аналіз діяльності транспортних бірж в Україні. Транспортні системи та технології перевезень. 2019. № 17. C. $22-27$.

12. Кушим Б., Сілантьєва Ю. Посередницька діяльність при здійсненні міжнародних автомобільних перевезень вантажів. Сучасні тенденції розвитку науки : матеріали IV Міжнародної науково-практичної конференції, м. Чернівці, 21-22 грудня 2018 р. Чернівці, 2018. С. 92-93.

13. Лісіца Т. ЗЕД: Посередницькі договори. Офіційно про податки : вісник. 2017. № 39 (943). URL: http://www.visnuk.com.ua/ uk/publication/100006049-zed-poserednitski-dogovori.

14. Посередник. Академічний тлумачний словник. 1970-1980. URL: http://sum.in.ua/s/poserednyk.

15. Посередницькі договори в підприємця. OSTAPP journal. URL: https://journal.ostapp.com.ua/uk/articles/post/posredniceskiedogovory-u-predprinimatela.

16. Прайс-агрегаторы цен товаров в Украине: 15 площадок для размещения. URL: https://advermedia.ua/blog/prajs-agregatoryukrainy-rassmatrivaem-plyusy-i-minusy/.

17. Самойленко Г. Особливості цивільно-правового регулювання перевезень пасажирів, здійснюваних 3 використанням мобільних додатків Uber та BlaBlaCar. Підприємництво, господарство і право. 2018. № 9. С. 29-34.

18. Соколова А. Что такое агрегатор. Объясняем простыми словами. URL: https://secretmag.ru/enciklopediya/chto-takoeagregator-obyasnyaem-prostymi-slovami.htm.

19. Традиционные транспортные компании и агрегаторы могут существовать параллельно. URL: https:/www.rzd-partner.ru/ logistics/opinions/traditsionnye-transportnye-kompanii-i-agregatory-mogut-sushchestvovat-parallelno/.

20. Транспортные агрегаторы информации или прямой исполнитель транспортных услуг. Com-stil.com. 2021. URL: https://comstil.com/blogs/transportnyie-birzhi-ili-sajt-transportnoj-kompanii.

21. Угода користувача «Ларді-Tранс». URL: https://ardi-trans.ua/uk/about/article/12/.

22. Умови використання inDriver. URL: https://indriver.com/ru/offer/.

23. Умови користування платформою BlaBlaCar. URL: https://blog.blablacar.com.ua/about-us/terms-and-conditions.

24. Что такое платежный агрегатор? URL: https://blog.easypay.ua/ru/chto-takoe-platezhnyiy-agregator/

25. Чупрін Є., Кондратенко Д., Гелеверя Є. Аналіз та перспективи розвитку транспортної галузі України з позиції автотранспортних підприємств. Науковий вісник Ужгородського начіонального університету. Серія «Міжнародні економічні відносини та світове господарство». 2019. Вип. 24 (3). С. 125-130. 


\section{Омельчук Олексанар Сергійович, БонАар Павло ВаАимович \\ ПРАВОВА ПРИРОАА АОГОВІРНИХ ВІАНОСИН ПЕРЕВЕЗЕННЯ 3 ВИКОРИСТАННЯМ ТРАНСПОРТНИХ AГРЕГАTOPIB}

Об'єктом АосліАження виступають віАносини між користувачами платформ транспортних агрегаторів та самими транспортними агрегаторами. У межах статті досліАжуються питання місця транспортних агрегаторів у сучасних транспортних правовіАносинах, функцій транспортних агрегаторів та переваг, які вони наАають перевізникам та замовника послуг перевезення.

Визначено сутність поняття “агрегатор", з'ясовано переваги останніх перед звичайними рекламними майданчиками. Проаналізовано види агрегаторів, визначено місце транспортних агрегаторів сереА інших агрегаторів товарів та послуг. Визначено, що агрегатори не зАійснюють пошук постачальників та клієнтів, а використовують IT-рішення, що Аозволяють сторонам договору самим знаходити потрібні товари та послуги.

Класифіковано транспортні агрегатори за критерієм статусу суб'єктів відносин у сфері перевезень (Р2P, В2Р та В2В, тобто між фізичними особами, між суб'єктами підприємництва та юридичними особами, змішані); за ступенем доступності виАілено загальнодоступні та умовно закриті транспортні агрегатори (такі, що співпрацюють 3 обмеженим колом компаній); віАповідно Ао видів перевезень запропоновано розрізняти агрегатори авіаційного, залізничного, автомобільного, водного транспорту, універсальні транспортні агрегатори; за критерієм призначення перевезень виАіляють агрегатори пасажирських перевезень та вантажно-транспортні біржі. Проаналізовано особливості характеру окремих видів транспортних агрегаторів.

Аоведено, що найбільш важливим Аля науки цивільного права критерієм класифікації відповіАних транспортних відносин $€$ правовий статус транспортного агрегатора, зміст його прав і обов'язків у віАповіАних віАносинах. А^я коректного визначення меж правового статусу транспортного агрегатора проаналізовано завдання та функції конкретних транспортних агрегаторів. ВіАзначено, що питання визначення юридичного статусу транспортного агрегатора у відносинах надання послуг перевезення пасажирів та вантажу не має однозначного вирішення. у літературі діяльності транспортних агрегаторів надають характер посередницької, інформаційної, комунікаційної, експедиторської діяльності або визначають основною метою транспортних агрегаторів організацію перевезення й оптимізацію перевізного процесу. ВіАсутність єАності погляАів на суть Аіяльності транспортних агрегаторів пояснюється неоднорідністю функцій конкретних агрегаторів, отже, ступенем віАповіАальності за порушення умов Аоговору послуг перевезення.

Зроблено висновок, що правовий статус транспортних агрегаторів визначається на договірних засадах долучення користувача до агрегатора та зумовлюється його ром^ю в безпосередніх відносинах між замовником та виконавцем послуги перевезення. Межі цивільної віАповіАальності транспортного агрегатора залежать віА того, чи є він посередником, налає інформаційні послуги або є безпосереднім виконавцем за договором перевезення.

Ключові слова: транспортні агрегатори, транспортні біржі, Аоговір перевезення, правова природа, правовий статус, спільні поїзАки, посереАницькі договори, Аоговір інформаційних послуг

\section{Omelchuk Oleksandr, Bondar Pavel}

\section{LEGAL NATURE OF CONTRACTUAL RELATIONS WITH TRANSPORTATION USING TRANSPORT AGGREGATES}

The object of the study is the relationship between users of transport aggregator platforms and the transport aggregators themselves. The article examines the place of transport aggregators in modern transport relations, the functions of transport aggregators and the benefits they provide to carriers and the customer of transportation services.

The essence of the concept of "aggregator" is defined and the advantages of the latter over the usual advertising platforms are clarified. The types of aggregators are analyzed, the place of transport aggregators among other aggregators of goods and services is determined. It is determined that aggregators do not search for suppliers and customers, but use IT solutions that allow the parties to the contract to find the necessary goods and services.

Transport aggregators are classified according to the status of subjects of relations in the field of transportation (P2P, B2P and B2B); to the degree of availability (publicly available to conditionally closed transport aggregators); to the types of transportation (aggregators of air, railroad, water transport and universal transport aggregators;) to the criterion of purpose of transportations (aggregators of passenger transportations and freight exchanges). The peculiarities of the character of separate types of transport aggregators are analyzed.

It is proved that the most important criterion for the science of civil law to classify the relevant transport relations is the legal status of the transport aggregator and the content of its rights and obligations in the relevant relations. To correctly determine the boundaries of the legal status of the transport aggregator, the tasks and functions of specific transport aggregators are analyzed. It is noted that the issue of determining the legal status of the transport aggregator in relation to the provision of passenger and cargo transportation services does not have an unambiguous solution. In the literature, the activities of transport aggregators give the character of intermediary, information, communication, forwarding activities or determine the main purpose of transport aggregators, the organization of transportation and optimization of the transportation process. The lack of unity of views on the essence of the activities of transport 
aggregators is explained by the heterogeneity of the functions of specific aggregators and, accordingly, the degree of responsibility for breach of contract of transportation services.

It is concluded that the legal status of transport aggregators is determined on a contractual basis by the user's involvement in the aggregator and is determined by its role in the direct relationship between the customer and the service provider. The limits of civil liability of the transport aggregator depend on whether it is an intermediary, provides information services or is a direct executor under the contract of carriage.

Key words: transport aggregators, transport exchanges, contract of carriage, legal nature, legal status, joint trips, intermediary agreements, contract on information services. 